\title{
Współpraca kapłana i psychiatry w celu przywrócenia zdrowia człowieka
}

\author{
ks. Piotr Pietkiewicz \\ Diecezja Białostocko-Gdańska \\ Polska \\ kspietkiewicz@poczta.onet.pl
}

Fr. Piotr Pietkiewicz, Cooperation of Priests and Psychiatrists in Restoring Health, Elpis, 18 2016: 133-136.

\begin{abstract}
We can divide various of attitudes concerning human mental illnesses into three basic categories: firstly, only priests dealt with it; secondly, their role is denied and omitted; and thirdly, medicine and theology co-operate together. The diagnostic tests made by the author have shown the need for cooperation between doctors dealing with mental health issues and priests taking care of spiritual health. A psychiatrist should not replace a priest or vice versa. Each, within the limits of his competences, should fulfil the role for which he has a vocation. The priest should take care of a patient's spiritual life thanks to which a person forms his relationship with God, whereas psychiatrist should care for psychophysical life, in which the brain and the nervous system direct all life functions

Streszczenie: Podejście do problemów psychicznych człowieka można podzielić na trzy zasadnicze okresy: w pierwszym chorobami psychicznymi zajmowali się tylko duchowni, w drugim ich rola była negowana i pomijana oraz trzeci będący okresem współpracy medycyny i teologii. Przeprowadzone przez autora badania diagnostyczne ukazały potrzebę rozwijania współpracy pomiędzy lekarzami zajmującymi się zdrowiem psychicznym i kapłanami dbającymi o zdrowie duchowe człowieka. Lekarz psychiatra nie powinien zastępować duchownego, ani na odwrót. Każdy w granicach swych kompetencji powinien wypełniać rolę, do której został powołany. Kapłan powinien dbać o życie duchowe człowieka dzięki któremu nawiązuje on relację z Bogiem a psychiatra o życie „duszewne”, czyli psychofizyczne, w którym mózg i układ nerwowy kieruje wszystkimi funkcjami życiowymi ciała.
\end{abstract}

Keywords: mental health, spiritual health, psychiatrist, priest, diagnostic tests

Słowa kluczowe: zdrowie psychiczne, zdrowie duchowe, lekarz psychiatra, kapłan, badania diagnostyczne

Relacje między medycznym i teologicznym podejściem do problemów człowieka można scharakteryzować w trzech okresach.

Pierwszy $\mathrm{z}$ nich (do XIX w.) to okres religijno-mistycznego postrzegania wszelkich psychopatologicznych problemów. W tym czasie psychiatria jako nauka jeszcze nie istniała. Wszystkie choroby psychiki traktowano jako bezpośredni skutek grzechu pierworodnego i rezultat opętania wynikający z działania złych duchów. Logicznym więc przekonaniem w tym okresie było to, że zajmować się i leczyć takich ludzi powinni nie lekarze, lecz duchowni. $\mathrm{W}$ tym czasie osoby chore umieszczane były pod opieką monasterów, w których należy doszukiwać się początków narodzin psychiatrii. Mnisi opiekując się chorymi, dzięki modlitwie, cierpliwości i współczującej miłości, starali się przynieść im ulgę $\mathrm{w}$ cierpieniach.

Drugi z etapów to okres narodzin psychiatrii jako naukowej dyscypliny medycznej (od II poł. XIX). W tym czasie twierdzono, że choroby psychiczne w niczym nie różnią się od chorób somatycznych. Okres ten cechuje także negacja roli wiary i kapłana, jako nieistotnej dla zdrowia chorego. Religijność pacjentów zaczęto traktować jako symptomy choroby, bądź obsesje. Człowieka sprowadzono do czysto fizjologicznych procesów, w których dopatrywano się także źródła jego stanów psychicznych, traktując je jako objawy funkcjonowania układu nerwowego. W ówczesnym języku medycznym nie było już miejsca na takie terminy jak: dusza, życie duchowe, sumienie. Człowieka pojmowano w kategoriach funkcjonowania jedynie fizycznego i społecznego. Propagowano podejście racjonalistyczne, w którym możliwym było wyjaśnienie wszelkich problemów i przeżyć duchowych przez lekarzy psychiatrów, bądź psychologów ${ }^{1}$. Nadawanie im charakteru religijnego i zwracanie uwagi na transcendencję, było wówczas zachowaniem niestosownym, które nie przystoi osobom światłym i wykształconym².

Trzeci okres, który rozpoczął się w końcu XX wieku i trwa do dzisiaj, to czas, w którym, w celu określenia norm zdrowia i patologii, w psychologii i psychiatrii zrodziła się konieczność syntetycznego przeglądu problemów psychiki ludzkiej ${ }^{3}$. W podejściu do człowieka, zaczęła przeważać tendencja ujmowania go w całej pełni jego istnienia, dostrzegając duchowy i psychofizyczny wymiar życia. W praktyce

Por. Z. Pasek, Od religijności ku duchowości. Przyczynek do przemian kultury współczesnej, „Idee i Myśliciele”, I. Fiut (red.), Kraków 2008, s. 20-24.

2 Ateistyczne tendencje $\mathrm{w}$ psychologii były normą realizowaną przez większość uczonych w XIX i XX wieku. Jednak mimo panującej skrajnej negacji duchowości w człowieku, byli wówczas także ludzie, którzy w tych trudnych czasach potrafili dawać inne odpowiedzi na nurtujące problemy człowieka postrzegając go przez perspektywę jego duchowości. Wśród prawosławnych był to np. lekarz-chirurg św. abp Łukasz Wojno-Jasieniecki biskup Symferopola i Krymu.

${ }^{3}$ Por. J. Prusak, Religia i duchowość w psychoterapii, [w:] Podstawowe zagadnienia psychologii religii, S. Głaz (red.), Kraków 2006, s. 426. 
terapeutycznej zaczęto zezwalać na oddziaływanie religijne na pacjentów, dostrzegając pozytywny wpływ modlitwy i sakramentów. Coraz częściej można w szpitalach psychiatrycznych zauważyć też kaplice i księży kapelanów.

Obecnie pojawia się coraz więcej książek na temat uwzględniania duchowości i religijności w psychoterapii oraz artykułów w naukowych wydawnictwach opisujących wyniki badań w tym zakresie ${ }^{4}$.

Po okresie ostrych napięć między psychiatrią a religią, obecnie zaleca się zwracanie uwagi na czynnik religijny w diagnozie i leczeniu, nie traktując go już jedynie jako czynnika chorobowego. W dzisiejszej psychiatrii w XXI wieku zauważa się już wzajemny związek między stylem życia i religijnością człowieka, jego stosunkiem wobec kwestii moralnych, a zdrowiem psychicznym. W literaturze psychiatrycznej na świecie coraz liczniej pojawiają się artykuły postulujące uwzględnianie duchowego wymiaru życia pacjentów, akcentujące rozmowę z pacjentami o ich życiu duchowym, czy namawianie pacjenta do kontaktu $\mathrm{z}$ duszpasterzem.

Pismo Święte mówi bardzo wyraźnie o tym, że korzystanie z pomocy lekarza nie przekreśla pomocy duchownego i odwrotnie: Czcij lekarza czcia należna z powodu jego posług, albowiem i jego stworzył Pan. Od Najwyższego pochodzi uzdrowienie, $i$ od Króla dar się otrzymuje. Wiedza lekarza podnosi mu głowe, nawet $i$ wobec możnowładców będa go podziwiać. Pan stworzył z ziemi lekarstwa, a człowiek mądry nie będzie nimi gardzit [...] Synu, w chorobie swej nie odwracaj się od Pana, ale módl się do Niego, a On cię uleczy. [...] sprowadź lekarza, bo jego też stworzyt Pan, nie odsuwaj się od niego, albowiem jest on ci potrzebny. Jest czas, kiedy w ich rękach jest wyjście z choroby (Syr 38,1-13).

$\mathrm{W}$ wyniku przeprowadzonych badań diagnostycznych ${ }^{5}$ okazało się, że: $86 \%$ lekarzy psychiatrów podczas swej praktyki zawodowej, spotkało się u swych pacjentów z problemami religijnymi (dotyczyło to wg nich $14,1 \%$ pacjentów). Także $90 \%$ duchownych przyznało, że w swojej pracy duszpasterskiej mieli kontakty z osobami przeżywającymi problemy natury psychicznej (kapłani zauważyli to u 2,1 $\%$ wiernych). Taka ilość przypadków dostrzeganych zaburzeń, powinna być ważnym argumentem za nawiązaniem szerszej współpracy lekarzy i kapłanów.

Podczas kontaktu kapłana $\mathrm{z}$ wiernym oraz psychiatry z pacjentem należy strać się określić, czy problemy danego człowieka mają swe podstawowe źródło w duchowych, czy w psychicznych sferach jego życia. Które zachowania wynikają z naruszenia systemu wartości zasad moralnych, a któ-

Zob. A. Ostaszewska, Badania nad efektywnościa włączania tematyki duchowości i religijności w psychoterapii, „Psychoterapia” 2(169) 2014, s. 5.

5 Badania diagnostyczne przeprowadzone zostały przez ks. Piotra Pietkiewicza w 2012 roku wśród kapłanów Prawosławnej Diecezji Białostocko -Gdańskiej z dekanatów: białostockiego, gródeckiego, sokólskiego oraz lekarzy psychiatrów z placówek służby zdrowia województwa podlaskiego, w miejscowościach: Białystok i Choroszcz. Analizowana grupa badawcza liczyła 100 osób, udział kapłanów i lekarzy był taki sam i wynosił $50 \%$. Badania przeprowadzone zostały metodą kwestionariusza anonimowej ankiety, stosując metodę ilościową. Wyniki poddane zostały analizie matematyczno-statystycznej, stosując metodę indukcji oraz metodę porównawczą. re są skutkiem nieprawidłowego funkcjonowania mózgu i układu nerwowego i wymagają medycznych kompetencji. Istnieją także trudne sytuacje złożone, w których jednocześnie w człowieku występują choroby duchowe i psychiczne. Wtedy niezbędna jest szczególna umiejętność analizy osobowości człowieka.

Człowieka chorego psychicznie możemy rozpoznać po tym, że ma problem z obiektywną oceną swego aktualnego stanu zdrowia. Nie panuje nad własnym zachowaniem, brakuje mu świadomej oceny pojawiających się myśli, nielogicznie interpretuje fakty, uczucia oraz rzeczywistość wokół siebie. W takich przypadkach wskazanym jest, aby kapłan w stosowny sposób zasugerował wiernemu kontakt z lekarzem psychiatrą.

Często zaburzeniom psychicznym osób religijnych towarzyszą, np. widzenia, prorocze sny, urojenia religijne (w których mają kontakty $\mathrm{z}$ istotami nadprzyrodzonymi aniołami, świętymi), towarzyszy im przekonanie, że są medium, które przynosi nieszczęście lub, że są opętani i zniewoleni przez złe duchy.

Na zaburzenia zdrowia psychicznego składają się najczęściej takie choroby jak: depresje, nerwice, schizofrenia (rozszczepienie osobowości), psychozy, zaburzenia dysocjacyjne (utrata prawidłowej integracji pamięci i poczucia własnej tożsamości), lęki, fobie, bulimia, anoreksja, dysfunkcje seksualne, otępienie po udarach, upośledzenia umysłowe, zaburzenia rozwoju psychicznego, np. autyzm, zaburzenia zachowania i emocji, np. ADHD, tiki, jąkanie, zatrucia substancjami psychoaktywnymi, uzależnienia.

Dużą trudnością dla wielu kapłanów jest sprecyzowanie roli lekarza psychiatry i przestrzeni, w której powinien on działać. Według prawosławnej antropologii człowiek stworzony został przez Boga $\mathrm{z}$ dwóch zasadniczych elementów: materialnego ciała i duchowej nieśmiertelnej duszy. W duszy człowieka można wyróżnić sferę duchową, dzięki której nawiązuje ona relację z Bogiem i „duszewną”, poprzez którą kieruje ona funkcjami życiowymi ciała. Dusza korzysta z ciała, uzewnętrzniając i wyrażając swe istnienie. Czyni to poprzez rozum, uczucia, wolę, dzięki pracy mózgu, który jest najważniejszym organem w organizmie. Od jego sprawności zależy świadomość człowieka jako osoby i poziom życia psychicznego.

Zaburzenia psychiczne nie wynikają z tego, że ktoś urodził się z ułomną duszą, lecz z tego, że dusza ma problemem z ciałem, które nie podporządkowuje się należycie jej władzy, przez co zakłócony zostaje rozwój człowieka (podobnie jak muzyk nie zagra harmonijnie na zepsutym, nienastrojonym instrumencie).

Mając to na uwadze można stwierdzić, że psychiatra, chcąc pomóc duszy, przede wszystkim leczy ciało, a ściślej mówiąc pomaga usprawnić mózg i jego funkcjonowanie w układzie nerwowym, aby dusza mogła $\mathrm{z}$ niego właściwie korzystać. Czyni to poprzez wsparcie farmakologiczne, bądź korzystając z różnych technik psychoterapeutycznych, oddziałując na wolę człowieka, jego świadomość i emocje w celu przezwyciężania chorób oraz ich następstw.

Lekarz psychiatra nie powinien zastępować duchownego, ani na odwrót. Każdy w granicach swych kompeten- 
cji powinien wypełniać rolę, do której został powołany. Kapłan powinien dbać o życie duchowe człowieka, psychiatra o życie „duszewne”, czyli psychofizyczne.

Badania naukowe dowodzą, że wiara i religia chronią psychikę człowieka. Osoby wierzące, rzadziej doświadczają problemów psychicznych, krócej chorują i szybciej się rehabilitują. Zdrowie duchowe człowieka zależy przede wszystkim od przestrzegania systemu wartości moralnych, według których on żyje. Dusza zaczyna chorować, popełniając grzechy w trakcie rozwoju człowieka, w wyniku procesu jej kształtowania społecznego i duchowego. Jednak zdrowie duchowe człowieka zależy także i od kondycji psychicznej, tzn. jakości współdziałania duszy i ciała, czyli tego na ile ciało, a ściślej mózg i układ nerwowy, reagują na polecenia duszy.

Dusza korzysta z ciała, aby uzewnętrznić i wyrazić swe istnienie. Czyni to dzięki pracy mózgu, który jest najważniejszym organem w organizmie. Jeżeli dochodzi do jego uszkodzenia, to dusza takiej osoby nie jest w stanie wyrazić pełni swych możliwości. Problemy psychiczne wynikają więc przede wszystkim z uszkodzenia mózgu i układu nerwowego. Poza tym ich źródłem jest cierpienie wynikające $\mathrm{z}$ różnych życiowych zdarzeń (nieuleczalna choroba, śmierć kogoś bliskiego), konsekwencje chorób somatycznych (np. przy nowotworach skutkiem ubocznym chemioterapii są lęki), wpływ problemów życia duchowego (np. gdy ktoś dokonał aborcji i popada w depresję).

Wielką trudnością jest interpretacja stanu duchowego osób z zaburzeniami psychicznymi. Nie należy każdego chorego psychicznie traktować jako chorego duchowo. Osoba doświadczająca pewnych zaburzeń psychicznych, jeśli jest osobą pobożną (czyli praktykującą modlitwę osobistą i uczestniczącą w życiu sakramentalnym), to dzięki łasce Bożej może nie doświadczać wielu duchowych skutków wynikających z wadliwej pracy mózgu. Osoba z zaburzeniami może zachowywać całkowicie poprawną percepcję duchową (przynajmniej okresowo): prawidłowo rozumiejąc wartości ewangeliczne, rozróżniać dobro i zło, mieć właściwe poczucie grzechu oraz sprawiedliwości. Stanowi to interesujący efekt działania łaski Bożej, chroniący wierzących przed degradacją ich osobowości. Życie religijne jest dla nich źródłem pozytywnych bodźców, wspomagających poczucie własnej wartości oraz osobistej godności. W takich sytuacjach wsparcie duchownego jest bardzo ważne.

Także osoby, których niepełnosprawność wynika z trwałego uszkodzenia mózgu, choć są upośledzone umysłowo, to należy je traktować jajo duchowo zdrowe. Ich dusze są czyste ${ }^{6}$. Potrafią szczerze modlić się (na miarę swych możliwości), świadcząc o swojej miłości wobec Boga i ludzi. Są prawdziwi i uczciwi w swych uczuciach.

W przeprowadzonych badaniach $6 \%$ duchownych otwarcie przyznało że nie posiada żadnej wiedzy na temat problemów psychicznych i nie podejmuje tego typu wyzwań. Kontaktów z osobami chorymi psychicznie unika

\footnotetext{
Ewentualne naruszenia zasad przez takie osoby są to zachowania nieświadome, które nie należy rozpatrywać w kategorii grzechu, lecz traktować jako objaw dysfunkcji.
}

także 4\% badanych, którzy czują że ich wiedza jest znikoma. Poziom własnej świadomości i kompetencji w kontakcie z osobami chorymi psychicznie 66\% kapłanów uważa za niepewny, czyli niewielki w stosunku do potrzeb, ale lepiej czy gorzej starają się sobie radzić podejmując wyzwania. Kolejne 24\% sądzi, że nie ma problemów i ich wiedza jest wystarczająca, aby otoczyć chorych należną opieką duszpasterską. Połowa badanych lekarzy stwierdziła, że w swojej praktyce lekarskiej spotkała osoby duchowne, które negowały ich rolę, twierdząc, że problemy danego chorego rozwiązywane powinny być jedynie w sposób duszpasterski.

Z informacji od lekarzy dowiadujemy się na przykład o sytuacjach, gdy kapłan: bez konsultacji, zalecał choremu, aby przestał brać lekarstwa, uznając je za niekonieczne, osoba chora na anoreksję, nie przyjmując pokarmu z powodu choroby, została doceniona przez kapłana za swą wstrzemięźliwość i srogi post. W chorobie natręctw, która objawia się poprzez wyrażanie obraźliwych myśli wobec ludzi, a nawet Boga, chory na spowiedzi usłyszał od kapłana, że to grzech przeciwko Duchowi Świętemu, który nie będzie wybaczony. Chory załamał się tego rodzaju odpowiedzią i zdecydował, że w rozpaczy targnie się na swoje życie.

Tragiczną w skutkach ofiarą błędu opiekuna duchowego jest także przypadek rosyjskiego pisarza Mikołaja Gogola (zm. 1852). Kapłan nie dostrzegając u niego ewidentnej bardzo poważnej depresji, zamiast umacniać w nim nadzieję, ufności w dobroć i miłosierdzie Boże, opowiadał mu o karach i piekielnym potępieniu, które sprowadzają na siebie grzesznicy. W wyniku takiego postrzegania beznadziejności swego położenia, Gogol przeświadczony o swej niegodności, przeniknięty duchem pokajania, przestał przyjmować pokarmy i zmarł z wycieńczenia ${ }^{7}$.

Duchowny powinien wiedzieć, że kłamstwa histeryka, czy przekleństwa osoby obsesyjnej nie są grzechami, lecz objawami chorób, które powinny być leczone w gabinecie psychiatry.

Lekarze w swych ankietach wskazywali, że wielu kapłanów nie rozumie problemów psychicznych i brakuje im wiedzy, aby właściwie zinterpretować zaburzenia. Niektórzy negują też rolę psychiatrów w rozwiązywaniu problemów ludzi chorych. Niewątpliwie jest to czynnik utrudniający kontakt oraz terapię prowadzoną przez lekarzy, którzy zanim przekonają pacjenta do konieczności podjęcia leczenia, muszą zmierzyć się z siłą autorytetu duchownego. W wyniku tej niepotrzebnej „rywalizacji”, żadna ze stron nie zyskuje w oczach pacjenta, a jedynie osłabia swoją pozycję.

Niestety jedynie $52 \%$ badanych duchownych zna jakiegoś lekarza psychiatrę, do którego mogliby skierować po pomoc potrzebującą osobę. Średnio duchowni znają tylko jednego, bądź dwóch takich lekarzy. Prawie połowa (48\%) nie zna żadnego specjalisty zajmującego się zdrowiem psychicznym, co potwierdza fakt dużej izolacji obu środowisk.

Stan kontaktów środowiska duszpasterzy i lekarzy zajmujących się zdrowie-m psychicznym ludzi oceniany jest

zob. Pastyrskaja pomoszcz duszewnobolnomu, [w:] Nastolnaja kniga swiaszczennosłużtiela, t. 8, Moskwa 1988, s. 316-319. 
negatywnie prawie przez wszystkich badanych duchownych (96\%). Jako zadowalający poziom stosunków ocenia tylko $4 \%$ osób. Pozytywne nastawienie do współpracy kapłanów i lekarzy psychiatrów potwierdza także $96 \%$ badanych duchownych stwierdzających, że mogą i powinny się one uzupełniać. Rokuje to pozytywne nadzieje na przyszłość, gdyż badanie lekarzy psychiatrów wykazały podobną ocenę problemów, co świadczy o dobrej woli do współpracy po obu stronach.

Potrzebę edukacji z zakresu zdrowia psychicznego wyraziło 68\% spośród duchownych. Deklarują oni chęć rozwijania kontaktów i współpracy poprzez warsztaty, konferencje, wymianę doświadczeń. W pozostałej grupie jest $18 \%$ tych, którzy stwierdzili, że ich poziom wiedzy jest wystarczający i nie chcą podejmować żadnych działań edukacyjnych oraz 6 \% kapłanów, którzy zdecydowani są sami zadbać o swoją edukację oraz $8 \%$ tych, którzy nie są zainteresowani tego typu zagadnieniami.

Istnieje wiele problemów, które dzięki takiej współpracy mogłyby zostać wcześniej zdiagnozowane i dzięki udzielonej pomocy nie byłyby zauważalne dla innych, nie stając się poważnymi utrudnieniami w życiu osobistym danej osoby. Człowiek wierzący, doświadczając jakichś zaburzeń, często najpierw szuka pomocy w Cerkwi. Przystępuje do spowiedzi, prosi o wsparcie i radę. Zwrócić się do lekarza jest niektórym ludziom czasami dużo trudniej. Kapłan jest osobą dużego zaufania społecznego, ma autorytet, jego słowa wiele mogą dla danej osoby czasami znaczyć. W kontakcie duszpasterskim kapłan powinien umieć ocenić, czy problem ma wymiar tylko duchowy, czy jest potrzebna konsultacja ze specjalistą. Kapłan może skutecznie motywować do leczenia poprzez wsparcie duchowe osoby $w$ trudnych stanach, dzięki modlitwie oraz sakramentom. Może też pomóc przełamać, wciąż obecny w społeczeństwie, negatywny stereotyp lekarza psychiatry. Bardzo istotną rolą kapłana jest także kontakt i wsparcie duszpasterskie okazywane rodzinom osób chorych psychicznie. Niekiedy, gdy zdarzają się nieracjonalne, agresywne lub wulgarne zachowania chorych, cierpią osoby najbliższe i dochodzi do konfliktów $\mathrm{z}$ otoczeniem. Duchowny może w takich przypadkach pomóc choremu w odbudowie zepsutych relacji w rodzinach.

Istnienie współpracy pomiędzy lekarzem psychiatrą a duchownym jest świadectwem odpowiedzialnego podejścia każdej ze stron wobec problemów swych pacjentów i wiernych, czego skutkiem może być szybsza poprawa stanu ich zdrowia i satysfakcji z życia.

\section{Bibliografia}

Pasek Z., Od religijności ku duchowości. Przyczynek do przemian kultury współczesnej, „Idee i Myśliciele”, I. Fiut (red.), Kraków 2008.

Prusak J., Religia i duchowość w psychoterapii, [w:] Podstawowe zagadnienia psychologii religii, S. Głaz (red.), Kraków 2006.
Ostaszewska A., Badania nad efektywnościa właczania tematyki duchowości i religijności w psychoterapii, „Psychoterapia” 2(169) 2014.

Pastyrskaja pomoszcz duszewnobolnomu, [w:] Nastolnaja kniga swiaszczennosłużytiela, t. 8, Moskwa 1988.

Rozmiar artykułu: 0,6 arkusza wydawniczego 